\title{
La alacrana
}

\section{Andrés Torres-Scott}

1 día en que la alacrana picó a la bebé, ella encendió la televisión de la cocina y sirvió agua en la tetera.

En la pantalla se transmitía una tragedia bíblica, un desastre en una ciudad que no conocía huracanes ni tornados. Ella colocó la tetera en la estufa y buscó la tapa en el cajón de los sartenes. En la tele había hileras de casas cubiertas por el agua y otras más que se llevaba el río. La televisión sentenció:

-Es el calentamiento global, los CFC, cuestión que nos hace responsables...

"A las aguas no les interesa el calentamiento global ni los CFC, 'Cualquier Fucking Cosa' que sean”, pensó, y sonrió al dar significado al acrónimo.

Abrió el anaquel para sacar la taza roja, su favorita, le puso una bolsita de té de camomila. Por alguna razón recordó un reportaje que leyó en la sala del dentista y que decía que los gases de una vaca emiten más dióxido de carbono que un automóvil encendido.

"Un científico afirma, con los pedos de la vaca en la mano, que cien reses contaminan más el aire que un embotellamiento”, pensó, y se echó a reír.

- Según este informe - dijo en la tele una chica rubia y de seguro vegana- los nuevos virus porcinos y avícolas son generados por culpa nuestra...

“iVálgame el Señor! iCreamos virus nuevos!”, pensó, y miró su mano sujetar la taza. Había en el dorso de su mano tres o cuatro diminutos bichitos que ella aplastó de inmediato para luego enjuagar en el fregadero como si fueran mugre.

-En el zoológico los únicos animales muertos durante la inundación fueron los peces. Los otros subieron a las zonas altas — dijo la tele y ella sonrió por la ironía de la naturaleza. El televisor mostraba imágenes de la inundación urbana que sin la menor culpa acarreaba autos, casas, personas y también árboles y hasta rocas-. La naturaleza se defiende, responde al ser humano... — dijo una voz desde la tele.

"No somos tan importantes. Para la naturaleza es igual un pez que una persona", pensó con la tapa de la tetera en la mano. "La naturaleza destruye sin distinguir. La 
naturaleza no se defiende, la naturaleza sólo es. Pregunten a los dinos”. Ella acercó el bote de miel y encendió la estufa.

Escuchó entonces el grito de la nena. Corrió por las escaleras y la encontró llorando sin tregua en la cuna colgante al centro de la habitación. Metió ambas manos debajo de la cobija rosa y la levantó.

La alacrana estaba inmóvil, en medio del colchón blanco, a unos centímetros de la coqueta almohada con funda de encaje rosa. Era del tamaño de un dedo y de color negro, aunque parecía tener manchas y estar hecha de plástico.

Frunció el ceño, parecía que las manchas en el bicho se movían. Se acercó. Encima del engendro circulaban varios críos, algunos dorados y, los menos, transparentes. Miró el suelo en busca de un zapato, sólo halló muñecos de peluche y el chupón de la niña. Revisó a la bebé y le sintió caliente la parte trasera del muslo. La descubrió y halló el punto negro donde la había picado. Parecía la inocente raíz de un pelo con aureola rojiza, un milimétrico epicentro desde el cual las arterias de la pierna se extendían moradas, como delgadas ramitas secas.

Bajó con la niña en brazos, iba tranquila, apagó la estufa, tomó las llaves del auto. Sentó a la niña en su sillita del asiento trasero y ajustó el enjambre de cinturones. Al mirar el volante empezó a perder la compostura. No supo si conducir al hospital o a la farmacia. Quizá sólo era cosa de comprar un antihistamínico que evitara un choque anafiláctico. Encendió el auto con brusquedad y aceleró de manera abrupta. La niña no dejó de llorar en su sillita desde el asiento trasero. Frenó de forma intempestiva ante la primera farmacia que apareció en su camino. Bajó del auto y no supo si traerse a la niña o dejarla en su silla. Decidió subir de nuevo al coche y conducir directo al hospital, si el antídoto era imprescindible ya lo inyectarían allá. Aceleró hacia donde dos semanas atrás dio a luz, en el trayecto no dejaba de repetirle en voz alta:

- Mi chiquita, mi nena, mi muñequita, hermosa, mi bebé, vas a estar bien, bonita, mira ya vamos, mira ya llegamos, princesa, preciosa...

Detuvo el auto en la entrada de emergencias y bajó con la nena en brazos. Una enfermera vestida de blanco le recibió a la bebé mientras ella explicaba que recién la había picado una alacrana. La enfermera insistió en que no podía dejar el auto en la bahía de urgencias.

A pesar de la circunstancia, le pareció que la enfermera tenía razón y fue a estacionar el auto de forma correcta. Sólo encontró lugares disponibles hasta la quinta sección, no le quedó más que correr de vuelta a la sala de urgencias. Jalaba aire por la boca, le dolía algo debajo de las costillas del lado derecho y sentía que se ahogaba 
a cada paso. A la distancia vio que, en la calle, sobre la entrada de urgencias, estaba un hombre de bata blanca con la nena llorando en brazos.

- Señora, no tenemos suero. Nunca habíamos atendido una picadura... Tiene que llevarla a...

Muda, le arrancó a su hija de las manos y corrió de vuelta al coche. Estuvo a punto de caerse en tres ocasiones y en una de ellas, quizá en la segunda, se quitó y abandonó las zapatillas. En el auto, otra vez acomodó a la nena en su sillita y sintió con los dedos sus mejillas coloradas que hervían como tamales en la olla.

"El hospital público. Ahí deben tener suero", pensó, y encendió el auto. Durante el viaje la bebé dejó de llorar, pero ella no paró de consolarla.

-Ya, ya, ya, mi chiquita, mi nena, mi muñequita. Nena hermosa, mi bebé, vas a estar bien, bonita, mira ya, mira ya llegamos, princesa, preciosa...

Al llegar, prefirió no detenerse en emergencias y fue a estacionarse. Corrió con la bebé en brazos. Cuando salió del estacionamiento y vio el edificio del hospital tan lejano se arrepintió de no haberse detenido en urgencias para bajarla. Corrió más rápido, algo le cortó el pie derecho, pero ella no se daría cuenta hasta el día siguiente.

En emergencias la enfermera que registró a la niña le dijo que sí había suero y de inmediato fue a sacar a un pediatra de un consultorio. El médico le descubrió la pierna a la nena. Sorprendidos, el médico, la enfermera y ella vieron que la mancha no era ya roja, sino púrpura, y que las venas que antes se veían como tenues líneas moradas ahora eran ramas vivas y gruesas que extendían una negritud purpúrea hasta la espalda y llegaban hinchadas al vientre, hasta al ombligo, de dónde todavía colgaba un pedacito del cordón umbilical recién cortado. La nena ya no tenía la cara ardiente ni colorada, estaba pálida, más cercana al amarillo que al blanco, y en sus ojos medio cerrados no se veían pupilas.

— Salga señora. Voy a ponerle el antídoto — dijo el médico.

—iEstá muy mal?

Fue a la sala de espera. Al dejarse caer en la silla sintió su celular en la bolsa trasera de los jeans. Marcó a su marido:

—Un alacrán picó a la niña. No, no. Fue en casa... iEn su cuna! No, donde nació no tienen antídoto. En fin, estoy en el hospital público. iVen! Sí. Mal. iYa, ven ya! —dijo y colgó.

Hace dos semanas la nena salió de su cuerpo y se la pusieron en los brazos. De inmediato, se pegó a su pezón y comió, nunca imaginó que eso era el amor: que alguien se alimente de tu seno.

La travesía para lograr ser padres fue un suplicio. Siete años de tratamientos de fertilización la destrozaron, pero cuando su marido se rendía al verla fatigada 
por lo agresivo del método para derrotar su innata inhabilidad reproductiva, ella contestaba:

—No. Todavía podemos intentarlo—. Ella siempre lo miraba a los ojos. —Una vez más, sólo una vez más. Sé que sí podemos.

Para el tercer año y sexto intento ella se embarazó, pero un inusitado aborto en el primer trimestre terminó con su esperanza. Contra todo pronóstico y contra la voluntad de su marido ella insistió en volver a intentarlo. Después de gastar más dinero del que tenían y aguantar más dolor de lo que imaginaba podría causar el procedimiento, la inseminación artificial pegó al séptimo año en quién sabe qué número de intento. Los dos pensaron y acordaron, sin platicarlo, no preguntar por el sexo del bebé, quizá porque así evitaban poner género a su posible dolor. Ella siguió a pie juntillas las instrucciones de los médicos y las cosas salieron a pedir de boca. La bebé nació de parto natural y pesó 2442 gramos.

Hace quince días regalaban chocolates a amigos y familia, quienes en reciprocidad traían flores y ropa y pañales y juguetes. Fue el mejor día de su vida, acostada en la cama del hospital su cuerpo servía de lecho para la nena y las dos dormían rodeadas por flores de colores. Dos días después del idílico reposo ella hizo su maleta para volver a casa y salió con la bebé envuelta en sus brazos y con el nuevo vicio de besuquear aquellas mejillas regordetas y esa nariz chiquita.

Su marido la abrazó. Ella se recargó en su pecho y se apretó contra él sin hablar. Al soltarse vieron al médico silente de pie a su lado, parecía llevar tiempo ahí sin querer interrumpir.

- ¿Es la mamá?

- Sí — contestó su esposo y no ella.

— ¿Y usted el padre?

—Sí — dijo su marido y afirmó con la cabeza.

—No, por favor, no... - imploró ella juntando las manos en su pecho al ver que el médico no terminaba de decir nada más.

- Lo lamento, señores. En verdad lo lamento.

La pesadilla ya había terminado y de ahí en adelante todo fue como un sueño. Firmó todo lo que le pasaba su esposo, perdió su celular y no encontró las llaves del coche. No se dio cuenta que iba descalza y con una cortada hasta que estuvo en la funeraria al día siguiente, cuando una amiga de la universidad le preguntó si no tenía frío en los pies, pues tenía los dedos morados. Alguien le dio unos calcetines y alguien más unas sandalias. 
Durante el velorio ella se sentó en un sofá negro de piel y no habló, no quiso hablar, no quería explicar a la peregrinación que llegaba y luego se sentaba a su lado lo sucedido. Sólo abrió la boca para beber agua y para escupir flemas que por alguna razón le emergían constantes desde la boca del estómago, como olas ininterrumpidas.

Lo abrazó, pero no lloró en el hombro de su marido. Mantuvo los ojos vidriosos todo el tiempo y no los cerró. Cuando quedó sola, con los ojos abiertos y perdidos en el horizonte de la absurda sala que en el centro tenía un diminuto y grosero féretro de madera marrón oscura rodeado por largas flores blancas, pensó en su hija y su pequeña nariz y sus mejillas gordas y sus labios pequeños, sus ruidos al dormir y los sonidos que hacía al respirar. Se le salieron tres sollozos sin lágrimas.

Había arreglos florales de todos los tipos posibles distribuidos por el suelo y un par de horribles cirios rosados que siempre estuvieron encendidos. Al fondo del salón, el nombre de la niña escrito con letras doradas en un listón rosado de una corona floral que alguien envió con mucho cariño, pero sin duda con más pena.

"Colgamos de un hilo", se dijo a sí misma, y le llegó a la mente la imagen de los deditos de los pies de la niña. "Es absurdo vivir dos semanas. Comer, mear, cagar, para luego sufrir y morir en menos de lo que está listo un té de manzanilla. O, ituvo mi nena una vida ideal?" Las imágenes de la alacrana y sus crías circulándole por el cuerpo de arriba a abajo sacaron de su cabeza la imagen de su hija. "iAmas a tus crías? ¿Prefieres a los dorados? ¿Te los comes? ¿Por qué me la picaste? ¿Sabes que me la mataste?”, pensaba, y recorría su cabeza de adelante para atrás con los diez dedos de las manos. "Ni siquiera lo sabes".

- Habla por favor, dime algo. Me preocupas — dijo su marido al llegar a casa.

-No te preocupes.

- Voy a bañarme.

Él subió y ella se metió a la cocina. En la mesa estaba la taza roja con la bolsita de té y en la estufa la tetera con el agua. Contempló la escena del té que no bebió, escurrió el agua de la tetera y la rellenó. El sonido del agua de la llave le recordó la inundación que vio en la televisión y que causó muerte y destrucción. Recordó también los pedos de las vacas, los dinosaurios, los virus mutantes, los comentarios estúpidos de la televisión. Encendió la estufa y colocó la tetera metálica en el quemador.

Abrió un cajón. Miró un cuchillo jamonero, largo, recién afilado, forjado para rebanar carne gruesa en rebanadas delgadas. Lo sujetó, recorrió el cuchillo con el dedo índice desde la punta hasta el mango de plástico negro. Lo botó en el cajón. Cogió otro cuchillo, más corto, dentado y con mango de madera. Era para cortar 
carne. Puso los dientes del cuchillo en la palma de la mano y la cerró, presionó con todas sus fuerzas. Contempló el recto rastro inocuo de los dientes del cuchillo en la palma de su mano y lo arrojó de vuelta. Miró otro cuchillo, pequeño, de una sola pieza, mango de metal y hoja curva. Era para quesos. Al cogerlo se rebanó un dedo, no recuerda cuál.

Mientras subía las escaleras, la yema de su dedo goteaba más sangre de lo que debería. Al llegar al pasillo del segundo piso escuchó el ruido de la ducha que tomaba su esposo. Apretó el mango metálico con tres dedos, lo pegajoso de la sangre le permitía sujetar a la perfección el arma. Se sintió confiada y fuerte. Hasta un poquito feliz.

Cruzó el umbral de la puerta y contempló la cuna colgante que tanto les había gustado. En tres pasos se colocó junto a ella. Levantó la cobija rosada y la inundó un olor a leche. Cerró los ojos y la memoria la traicionó al hacerle escuchar el llanto de la recién nacida.

-No, no es cierto.

Arrojó la cobija y clavó los ojos en la almohada con encaje rosado. La levantó de súbito con la mano izquierda.

"Solas, ahora sí".

Esta vez la alacrana no tenía a nadie recorriéndole el negro cuerpo reluciente. Ella no se inmutó al tenerla frente a frente en posición de ataque con cuchillo en mano y, al contrario, envalentonada, abrió sus brazos y elevó ambas pinzas para abrir y cerrar dos veces en un segundo.

—Clac-clac — dijo, y entonces, sin miedo, curveó la cola hacia adelante.

Ella dirigió el aguijón hacia arriba y lo apuntó a su cara, justo en medio de los ojos. En la cocina, ignorando el duelo, el agua hirviente hizo silbar la tetera.

ANDRÉs ToRRes Scott. Escritor chilango. Ganador del Premio Internacional de Narrativa Ignacio Manuel Altamirano 2013-2014 de la Universidad Autónoma del Estado de México (UAEM), México, por Un artista de la tortura, y del Premio Internacional de Novela Breve Rosario Castellanos 2007 con Y tú, iqué vas a hacer con tu millón?. Ha publicado en las revistas LetrA-Z de Argentina, Literatosis! de Uruguay y la mexicana Letras Explícitas. Sus textos han aparecido en publicaciones de Estados Unidos, México, España, Uruguay y Canadá. 